\title{
On the management of retained airgun pellets: a survey of 11 orbital cases
}

\author{
NICHOLAS A JACOBS AND LAURENCE H MORGAN
}

From the Manchester Royal Eye Hospital

SUMMARY Relevant factors determining the management of inaccessible retained lead airgun pellets are discussed in relation to 11 orbital cases. Although the injuries were of between one month's and 26 years' standing, serum lead levels were normal at under $350 \mu \mathrm{g} / \mathrm{l}$ in all instances. This is attributable to the modern alloy composition of the ammunition in question. It is concluded that surgical intervention may be indicated only where there is a mechanical disturbance of ocular motility allied with good visual function.

The question of whether or not surgical management of retained lead pellets is indicated has been raised recently. 'Possible dangers of extraction in anatomically complicated regions must be weighed against the risks of leaving the foreign body in situ. In the case of the orbit these risks would indeed have to be great to justify a difficult and exacting procedure. This is particularly true where the eye retains good visual function, as operative trauma to the optic nerve or its vascular supply would be irredeemable. In the absence of impaired ocular motility, fate might well be tempted by intervention.

This study of 11 patients with retained orbital lead pellets was carried out to assess the possible risks entailed in adopting a conservative approach. Apart from possible mechanical effects resulting from such a presence, we particularly examined the hazard of lead toxicity. Chronic lead intoxication was common in ancient times. More recently its incidence has fallen dramatically. In Britain 1058 cases were reported in 1900 and 107 in 1967. The first occupational risk to come under the scrutiny of Parliament was that of lead workers in 1883 with the Factories Act. ${ }^{2}$ In the past lead was used in the manufacture of many consumer products, though nowadays its most pervasive presence results from its addition to petrol.

The clinical picture of intoxication includes colicky abdominal pains, stomatitis with a blue line round the gums, polyneuritis with wrist drop, and encephalopathy. A microcytic anaemia with punctate basophilia is usually found. ${ }^{2}$ Ocular complications

Correspondence to N A Jacobs, FRCS, Department of Ophthalmology, Charing Cross Hospital, Fulham Palace Road, London W6 8RF. arise in 1 to $2 \%$ of systemic cases. Papilloedema, retinal haemorrhages, and vascular sheathing may be noted, as well as pupillary dilatation and extraocular muscle palsies. Optic neuritis along with involvement of the remainder of the visual pathway is usual, and encephalopathy may be associated with cortical visual loss. ${ }^{23}$ Treatment involves clearance by chelating with agents such as EDTA, dimercaprol, or penicillamine. Osmotic or surgical management of encephalopathy may be required. ${ }^{3}$

\section{Materials and methods}

Eleven patients with retained lead pellets in the orbit of varying duration were assessed. Ocular examination with visual result, orthoptic evaluation of eye movement where applicable, and radiological confirmation of anatomical site were carried out. Serum lead levels were measured at the National Occupational Hygiene Service Laboratories in Fallowfield, Manchester. The atomic absorption electrothermal liquid presentation method of lead level analysis was used.

\section{Results}

All patients had been shot with a typical 'narrow waisted' airgun pellet of 0.22 calibre, apart from one. Case 4 retained a copper coated lead ball. Ages at the time of injury ranged from 11 to 18 years for the males. The female in the series was 27 years old.

The duration of foreign body retention varied from one month to 26 years, being more than two years in six cases. All serum lead levels fell within the normal 
Table 1 Summary of case reports

\begin{tabular}{|c|c|c|c|c|c|c|c|c|c|c|}
\hline Case & eSex & Age & $\begin{array}{l}\text { Duration } \\
\text { of } \\
\text { retention }\end{array}$ & $\begin{array}{l}\text { Blood lead } \\
\text { (normal }<350 \\
\mu g / l)\end{array}$ & Eye & $\begin{array}{l}\text { Assailant } \\
\text { status }\end{array}$ & $\begin{array}{l}\text { Final } \\
V A\end{array}$ & Injury/action & Orthoptic findings & $\mathrm{x}$-ray location of pellet \\
\hline 1 & $\mathbf{M}$ & 18 & $26 \mathrm{yr}$ & $140 \mu \mathrm{g} / \mathrm{l}$ & $\mathbf{R}$ & Known & $6 / 6$ & $\begin{array}{l}\text { Eventual inferior retinal } \\
\text { pigment disturbance }\end{array}$ & NAD & $\begin{array}{l}\text { Posterior orbit: } \\
\text { inferolateral extraconal }\end{array}$ \\
\hline 2 & $\mathbf{M}$ & 11 & $8 \mathrm{yr}$ & $170 \mu \mathrm{g} / \mathrm{l}$ & $\mathbf{L}$ & NA & NPL & $\begin{array}{l}\text { Disorganised eye following } \\
\text { perforation injury }\end{array}$ & NA & NA \\
\hline 3 & $\mathbf{M}$ & 15 & $7 \mathrm{yr}$ & $190 \mu \mathrm{g} / \mathrm{l}$ & $\mathrm{L}$ & Known & NPL & $\begin{array}{l}\text { Disorganised eye following } \\
\text { perforating injury. } \\
\text { Primary repair }\end{array}$ & NAD & Apex orbit: superior \\
\hline 4 & $\mathbf{M}$ & 14 & $4 \mathrm{yr} 5 / 12$ & $\begin{array}{l}110 \mu \mathrm{g} / 1 \\
(\text { copper }= \\
12 \cdot 3 \mu \mathrm{mol} / \mathrm{l})\end{array}$ & $\mathbf{R}$ & $\begin{array}{l}\text { With } \\
\text { malice }\end{array}$ & $6 / 12$ & $\begin{array}{l}\text { Hyphaema. Inferior retinal } \\
\text { haemorrhage. Choroid } \\
\text { rupture }\end{array}$ & NAD & $\begin{array}{l}\text { Mid-orbital: inferior } \\
\text { intraconal }\end{array}$ \\
\hline 5 & $\mathbf{M}$ & 14 & 3 yr $7 / 12$ & $80 \mu \mathrm{g} / \mathrm{l}$ & $\mathbf{R}$ & Unknown & $6 / 4$ & Superior retinal commotio & NAD & $\begin{array}{l}\text { Apex of orbit: } \\
\text { superonasal }\end{array}$ \\
\hline 6 & $\mathbf{M}$ & 16 & 2 yr $5 / 12$ & $120 \mu \mathrm{g} / \mathrm{l}$ & $\mathrm{L}$ & $\begin{array}{l}\text { Self } \\
\text { inflicted } \\
\text { accident }\end{array}$ & AE & $\begin{array}{l}\text { Perforating injury. Repair } \\
\text { then enucleation }\end{array}$ & NA & $\begin{array}{l}\text { Mid-orbital: } \\
\text { superotemporal } \\
\text { extraconal }\end{array}$ \\
\hline 7 & $\mathbf{M}$ & 14 & $2 \mathrm{yr}$ & $90 \mu \mathrm{g} / \mathrm{l}$ & $\mathbf{L}$ & Unknown & $6 / 6$ & $\begin{array}{l}\text { Superior retinal } \\
\text { haemorrhage with } \\
\text { commotio. Choroid } \\
\text { rupture }\end{array}$ & NAD & $\begin{array}{l}\text { Mid-orbital: } \\
\text { superomedial } \\
\text { extraconal }\end{array}$ \\
\hline 8 & $\mathbf{M}$ & 12 & $1 \mathrm{yr} 3 / 12$ & $290 \mu \mathrm{g} / 1$ & $\mathbf{R}$ & Known & $\mathrm{AE}$ & $\begin{array}{l}\text { Perforating injury. Repair } \\
\text { then cnucleation }\end{array}$ & NA & $\begin{array}{l}\text { Temporal fossa after } \\
\text { breaching lateral } \\
\text { orbital wall }\end{array}$ \\
\hline 9 & $\mathbf{F}$ & 27 & 1 yr $2 / 12$ & $310 \mu \mathrm{g} / \mathrm{l}$ & $\mathbf{L}$ & Unknown & $6 / 9$ & Medial retinal haemorrhage & $\begin{array}{l}\text { Reduced left } \\
\text { adduction, } \\
\text { abduction and } \\
\text { elevation }\end{array}$ & $\begin{array}{l}\text { Mid-orbital: medial } \\
\text { extraconal }\end{array}$ \\
\hline 10 & $\mathbf{M}$ & 17 & $2 / 12$ & $170 \mu \mathrm{g} / 1$ & $\mathbf{R}$ & Known & $6 / 6$ & Inferior retinal commotio & NAD & Apex of orbit: inferior \\
\hline 11 & $\mathbf{M}$ & 15 & $1 / 12$ & $110 \mu \mathrm{g} / 1$ & $\mathbf{L}$ & $\begin{array}{l}\text { With } \\
\text { malice }\end{array}$ & $6 / 18$ & $\begin{array}{l}\text { Medial retinal commotio. } \\
\text { Orbital exploration with } \\
\text { medial rectus disinsertion }\end{array}$ & $\begin{array}{l}\text { Reduced left } \\
\text { adduction and } \\
\text { elevation }\end{array}$ & $\begin{array}{l}\text { Mid-orbital medial } \\
\text { extraconal }\end{array}$ \\
\hline
\end{tabular}

$\mathrm{VA}=$ visual acuity. $\mathrm{NA}=$ not available $. \mathrm{NAD}=$ no abnormality detected. $\mathrm{AE}=$ artificial eye. $\mathrm{NPL}=$ no perception of light.

range of less than $350 \mu \mathrm{g} /$ litre (Table 1), from $80 \mu \mathrm{g} / \mathrm{l}$ to $310 \mu \mathrm{g} / \mathrm{l}$. In the case of the copper coated pellet (case 4), the serum copper level was also normal, at $12 \cdot 3 \mu \mathrm{mol} / \mathrm{l}$ (normal range $12-20 \mu \mathrm{mol} / \mathrm{l}$ ).

There was no preference for the eye involved, with six of the 11 cases being left sided. In five accidental incidences the assailant was known to the victim, notably in case 6 , where it was the patient himself. In the other five cases in which histories were obtained three assailants were unknown and another two acted with malice. Good visual results of $6 / 12$ or better were found in six patients. A moderate result of $6 / 18$ was noted in a further patient. Two had no light perception, with disorganised eyes, and another two had had enucleation of their eye, with a prosthesis. In the less severe cases injuries included commotio retinae, intraretinal haemorrhage, and choroidal rupture. An unsuccessful orbital exploration which included disinsertion of the medial rectus muscle was performed in case 2.

Orthoptic studies of ocular motility in eight of nine relevant cases (excluding those two with artificial eyes) showed only two with limitation of eye movements. One of these (case 2) had undergone the exploratory procedure mentioned earlier. Radiology in 10 cases revealed three medially placed pellets, two of which were associated with orthoptic abnormalities, and two laterally placed pellets, with a third which passed through the lateral wall into the temporal fossa (case 8). Three more were located at the apex of the orbit, and finally one was found within the muscle cone.

\section{Discussion}

Reports of lead toxicity following shotgun wounds were frequent in the last and early part of this century. More recent accounts are less usual. In two series Leschke ${ }^{t}$ and Machle ${ }^{5}$ described six such cases. Machle ${ }^{5}$ stressed the dangers of delayed intoxication. Rossem and Vlaardingerbroek ${ }^{6}$ noted a severe injury, requiring later amputation of a leg, which caused acute lead intoxication in a matter of three days. Other chronic instances were recorded by Bile,? whose patient was successfully treated with $\mathrm{CaNa}_{2}$ EDTA, and Savic and Cosic, ${ }^{\mathrm{K}}$ who had one patient with all the laboratory findings of intoxication and another with negative findings. Fazzari and 
Formiconi, ${ }^{9}$ in their study of 17 cases, considered that the determination of urinary coproporphyrin would be useful, and agreed with Fabroni et al. ${ }^{11}$ in an account of 10 further cases that lead may be absorbed as a fatty compound. Neither of these series, nor that of six cases reported by Horiuchi et al.," included any examples of clinical intoxication, though raised levels in the blood and urine were present in some instances.

More recently Dillman et al. ${ }^{12}$ described a patient who developed a full clinical picture 20 years after retaining lead shot in a hip joint. On reviewing 18 further cases these authors surmised that a bony site of injury, particularly if exposed to synovial fluid, was likely to result in significant toxicity. Prompted by the above case of acute intoxication from the Netherlands, ${ }^{6}$ Schmidt et al. ${ }^{13}$ conducted animal experiments, and were unable to demonstrate toxicity from lead pellets. They ascribed this to developments in ammunition manufacture. Previously, soft or pure lead was used without any coating, whereas current hard shot alloy includes a small percentage of antimony (Sb), making it insoluble. As well as this, coatings such as graphite or lacquer may be applied. Morl et al. ${ }^{14}$ in a survey of a wide spectrum of military injuries, confirmed that lead intoxication is not to be expected from bullets made to modern specifications. Airgun pellets these days are made with a $0.5 \%$ antimony content. No coating is normally used, though coatings such as copper, nickel, or graphite are available. A lacquer coating is undesirable because excessive hardening may render the pellet more dangerous.

In this report the pellets were of 0.22 calibre, as is usual in such injuries. The lighter 0.177 calibre favoured by enthusiasts is both more accurate and less lethal. Bowen and Magauren, ${ }^{15}$ in a report of 105 ocular injuries from airgun pellets in Liverpool, failed to show evidence of lead toxicity in four patients selected from 16 with pellets retained in the orbit or ethmoid for between a few weeks and six years. This is in accordance with our negative findings in 11 such cases with a maximum retention of 26 years. However, a report of presumed local optic nerve toxicity from a lead pellet in the orbit was given by Dambite, ${ }^{16}$ where treatment with unithiol improved the visual function of the eye involved.

Visual prognosis for these patients depends on whether the eye has been perforated. Even where this has not occurred the kinetic energy of the event is such that severe blunt injury to the eye may be evident. This can take the form of hyphaema, iridodialysis, traumatic cataract, commotio retinae, vitreous haemorrhage, choroidal rupture, and retinal tears or detachment. In $24 \%$ of the series of 105 cases from Liverpool ${ }^{15}$ vision was $6 / 18$ or worse for such reasons. The remaining patients without perforating injury $(57 \%)$ retained good vision of $6 / 12$ of better. All but one of 16 perforated eyes was lost. Sevel and Atkins $^{17}$ conducted a postal survey of 87 cases in South Africa and noted good acuity where the eye was not penetrated. Useless eyes were not necessarily enucleated in this series, with 29 having perception of light or being totally blind. In view of the risk of sympathetic ophthalmitis, noted on one occasion by Bowen and Magauran, ${ }^{15}$ it may be more prudent to enucleate. Two patients in our report (cases 2 and 3 ) come into this category.

As regards the importance of possible mechanical effects, the Liverpool series included only one instance of ocular motility disorder. In that case the pellet was located at the apex of the orbit. There are two in this series, both with medially placed pellets. One of these (case 11) had exploratory surgery where the medial rectus was disinserted, and may therefore have been iatrogenic. In the other patient (case 9) the mechanism of restricted motility must remain speculative. It may result either from damage to extraocular musculature and its innervation, or else a mass effect and secondary tethering might be responsible.

Laffers and Brehm ${ }^{18}$ advocate the removal of orbital pellets, quoting two cases with postoperative improvement in ocular motility. In one instance though, a projectile larger than an airgun pellet was found. Duke-Elder stated that ${ }^{19}$ in the absence of definite indications an intraorbital foreign body should be left alone. Concurring with this viewpoint, Stallard $^{20}$ advised that a metallic foreign body less than $4 \mathrm{~mm}$ in diameter should not be removed unless there is pain, inflammation, or increasing disability. Because lead toxicity has not been found to be a complication, removal of retained orbital pellets should not be undertaken routinely. In those few cases where ocular motility is compromised and visual acuity reasonably good, recovery of the pellet can be considered.

\section{References}

1 Cudmore RE, Boothroyd A. Lancet 1985; i: 765-6.

2 Duke-Elder S. System of ophthalmology. London: Kimpton, 1972: 14 (2): 1235-8.

3 Greenseid DZ, Leopold IH. Toxic retinopathies. In: Duane TD, ed. Clinical ophthalmology. Philadelphia. Harper and Row, 1982: chapter 33: 9

4 Leschke E. Clinical toxicology. London: Churchill, 1934.

5 Machle W. JAMA 1940; 115: 1536.

6 Rossem C van, Vlaardingerbroek WM. Acute loodvergiftiging door een hagelschotverwonding. (Acute lead poisoning caused by shotgun pellets.) Ned Tijdschr Geneeskd 1965; 109: 1110-3.

7 Bile G. Saturnismo florido da ritenzione di proiettilo. (Florid lead poisoning from retention of bullets.) Lavoro Umano 1969; 21: $129-36$.

8 Savic J, Cosic V. Trovanje olovom prouzrokovano zaostalim projektilom. (Lead poisoning caused by a retained bullet.) Vojnosanit Pregl 1966; 23: 341-6. 
9 Fazzari C, Formiconi G. L'assorbimento del piombo da proiettili ritenuti nell'organismo. (Absorption of lead from projectiles retained in the organism.) Minerva Medicolegale 1965; 85: 41-5.

10 Fabroni F, Barni B. Barni I. In merito al saturnismo da ritenzione di proiettili multipli. (Lead poisoning by retention of multiple lead shot.) Giornale de Medicina Legale, Infortunistica et Tossicologia 1967; 12: 382-91.

11 Horiuchi $\mathrm{K}$. Horiguchi S, Utsunomiya $\mathrm{T}$, et al. Laboratory studies on the lead poisoning in six cases with lead shot lodged in the tissues. Osaka City Med J 1969; 15: 7-12.

12 Dillman RO, Crumb CK. Lidsky MJ. Lead poisoning from a gunshot wound: report of a case and review of the literature. $\mathrm{Am}$ J Med 1979; 66: 509-14.

13 Schmidt R, Schultka R, Franzen E. Klarung der Frage nach der Bleitoxizität handelsublichen Schrotes durch histochemische und chemische Untersuchungen. (Histochemical and chemical studies on the lead toxicity of small shots in commercial usage). Verhandlungen der Anatomischen Gesellschaft 1969; 63: 507-13.

14 Morl F, Schmidt R, Schultka R, Franzen E, Rautschke R.
Histochemical, spectrum analytic, and quantitative chemical lead studies and the problem of lead poisoning and buckshot injuries. Z Chir 1968; 93: 216-30.

15 Bowen DI, Magauran DM. Ocular injuries caused by airgun pellets: an analysis of 105 cases. Br Med J 1973; i: 333-7.

16 Dambite GR. Svintsovnaya atrofiya zritel'nogo nerva, uspeshno lechennaya unitiolom. (Successful treatment of lead atrophy of the optic nerve with Unithiol.) Oftalmol $Z h$ 1966; 21: 329-31.

17 Sevel D, Atkins AD. Pellet gun injuries of the eye. S Afr Med J 1978; 54: 566-7.

18 Laffers $\mathrm{Z}$, Brehm H. Intraorbitale, extrabulbar gelegene Projektilverletzungen. Klin Monatsbl Augenheilkd 1980; 176: 413-7.

19 Duke-Elder S. System of ophthalmology. London: Kimpton, 1972; 14 (1): 666-7.

20 Stallard HB. In: Roper-Hall MJ, ed. Stallard's eye surgery. Bristol: Wright, 1980: 843.

Accepted for publication 22 December 1986. 